Please do not remove this page

RMIT

UNIVERSITY

\title{
Cultural consumption and souvenirs: An ethical framework
}

Brennan, Linda-Marie; Savage, Theresa

https://researchrepository.rmit.edu.au/esploro/outputs/9921858155101341/filesAndLinks?institution=61RMIT_INST\&index=null

Brennan, L.-M., \& Savage, T. (2012). Cultural consumption and souvenirs: An ethical framework. Arts Marketing: An International Journal, 2(2), 144-160. https://doi.org/10.1108/20442081211274020

Document Version: Accepted Manuscript

Published Version: https://doi.org/10.1108/20442081211274020

Repository homepage: https://researchrepository.rmit.edu.au

(c) Emerald Group Publishing Limited

Downloaded On 2023/04/26 10:34:52 +1000

Please do not remove this page 
Thank you for downloading this document from the RMIT Research Repository.

The RMIT Research Repository is an open access database showcasing the research outputs of RMIT University researchers.

RMIT Research Repository: http://researchbank.rmit.edu.au/

\section{Citation:}

Brennan, L and Savage, T 2012, 'Cultural consumption and souvenirs: an ethical framework', Arts Marketing: An International Journal, vol. 2, no. 2, pp. 144-160.

See this record in the RMIT Research Repository at: http://researchbank.rmit.edu.au/view/rmit:17385

Version: Accepted Manuscript

Copyright Statement: (c) Emerald Group Publishing Limited

Link to Published Version:

http://dx.doi.org/10.1108/20442081211274020 


\title{
Cultural consumption and souvenirs: an ethical framework
}

\begin{abstract}
Purpose: - This paper proposes guidelines for business enterprises engaging with indigenous communities to protect their intellectual property rights, particularly indigenous art works produced for the souvenir industry.

Design/methodology/approach - Literature on indigenous art and souvenirs demonstrated exploitation of indigenous communities' intellectual property was facilitated by a lack of knowledge of how to otherwise behave. The proposed guidelines for commercial entities wishing to engage ethically with indigenous communities draws on international exemplars.
\end{abstract}

Findings $-A$ twelve-point framework for ethical commerce in indigenous souvenirs between indigenous communities and businesses is proposed to ensure populations lacking economic and social power are not disenfranchised by limited experience in a market society.

Social implications - The proposed guidelines contribute to achieving reconciliation between mainstream and indigenous people in various countries throughout the world.

Originality / value - This paper assists development of guidelines enabling ethical decisionmaking in the souvenir industry applying a critical approach to the principles of corporate responsibility.

Paper type - Conceptual

Keywords - corporate responsibility, cultural marketing, cultural copyright, intellectual property rights in cultural heritage, souvenir 


\section{Cultural consumption and souvenirs}

Souvenirs are central to the tourism experience, many tourists wanting to take home mementos of places they have been, and things they have done. These cultural artifacts are a means by which cultural memories are maintained once the person returns to their home environment. As well as providing a tangible object to take home that represents the memories of the place and experiences, souvenirs reap economic benefits for the hosts in the areas of design, production and sales. Together with shopping, souvenirs are lucrative aspects of expenditure in tourism, increasing nearly six percent in 2007 on a worldwide basis (United Nations World Tourism Organization, 2008, p. 3). Cultural tourists tend to look for authentic, quality souvenirs and for this reason many souvenir products are based on presenting images of what is iconic or indigenous to the host country or region. However, important to this context is the concept of 'ownership' of indigenous cultural heritage. As pointed out by Langton in Eric Micheal's (1994) book Bad Aboriginal Art "artists earn rights to paint certain preexisting designs, not to introduce new ones. Rights to a body of work are inherited" (p. xxxii). Thus 'outsiders' cannot 'own' artwork produced. She goes on to say that what is feared by community is the theft of the cultural inheritance by others not authorized (by their family connections) to make such art works.

Coate (2009) suggests more than ninety percent of indigenous auctioned art has been sold since the rise of the Papunya Tula art movement in the late 1960s. However, economic improvement at the auction end of indigenous art world, still leaves remote communities at risk of exploitation by more sophisticated 'marketers' of souvenir art. Since use of indigenous imagery and traditional cultural expression plays an important role in the development of souvenirs, it is therefore relevant to acknowledge that the semiotics of souvenirs depicting indigenous people, their culture or heritage impact not only the purveyors of souvenirs but also indigenous and other traditional and cultural populations around the world. Moreover, souvenirs carry potential benefits for the people who live in the host destination. Consequently, souvenirs made locally with local materials, by local people, would reduce the leaking of tourist money from the indigenous community.

In this conceptual paper, the aim is to set up ethical guidelines for commercial organizations that design, manufacture and sell souvenirs relating to the designs or identity of indigenous people. Much souvenir art is founded in 'First Stories.' That is, creation stories and/or dreamtime stories that are told in artifacts using traditional symbols and signs. Understanding the complexities of who owns aboriginal 'First Stories' and their relation to 'Country' is potentially beyond the scope of most commercial souvenir manufacturers whose main aim is to sell something representing a generalized nation such as 'Australia'.

Furthermore, the premise of this paper concurs with findings of the World Intellectual Property Organization (WIPO) that legal frameworks alone have not succeeded in preventing unauthorized exploitation, illicit use and abuse of traditional cultural expressions or folklore (WIPO, 2004, p. 16). WIPO advocates that indigenous and other traditional and cultural communities need to know about the laws and be able to exercise rights under the law. In order to effectively protect a community's traditional cultural expressions, WIPO calls for awareness-raising, training, legal aid, and access to institutions assisting communities manage and enforce their rights. But many indigenous and other traditional communities have multiple disadvantages, and reside in remote areas, and many such groups remain unaware of their legal rights or ability to pursue justice through legal channels. They are thus less likely to protect their intellectual property rights to traditional cultural expressions. An obligation to proactively address issues in the indigenous souvenir industry rests with more knowledgeable and economically and politically powerful business organizations.

This is an early version of a paper which eventually appears as Brennan, L., \& Savage, T. (2012). Cultural consumption and souvenirs: an ethical framework. Arts Marketing: an international journal, 2(2), 144-160. 
In addition to laws protecting indigenous imagery and cultural expression, a set of ethical guidelines for commercial organizations to follow when 'borrowing' from a traditional indigenous culture are proposed here. It is believed that this will achieve a heightened awareness of indigenous intellectual property rights and harmful effects of stereotyping in souvenir design, production, and sale. These guidelines find echoes in already-existing protective legislation such as the Berne Convention for the Protection of Literary and Artistic Works (1971). Developing these proposed guidelines applies a critical analysis of the principles of corporate responsibility in order to investigate the social and economic tensions at play. The terms corporate social responsibility (CSR) and corporate responsibility are used interchangeably here although their meanings differ in other contexts: here indicates a broader meaning than purely 'social'. Combining corporate sensibility with cross-cultural sensibility, may work towards healing misunderstandings between indigenous communities and well-off majorities in countries around the world. Debating the ethics of souvenirs depicting indigenous peoples and their heritage is one site of negotiating such change.

\section{Reclaiming culture}

Indigenous people around the world have begun to reclaim control of their culture from museums, universities and other collectors of indigenous artifacts (Fiskesjö, 2009; Hendry, 2005). According to Savage's (2005) ethnographic study on commodification of Ainu culture in Hokkaido, Japan 1988-2005, even experts in Ainu ethnography suffer from occasional criticism from individual Ainu people. For example, Hokkaido museum curators were severely criticized for displaying what they considered to be an historic item of Ainu material culture, a chastity belt. However, they failed to seek the opinions of Ainu women in the contemporary community even though one of the (male) curators was Ainu. If a museum organization has problems identifying offensive symbols, what chance does a commercial entity have, without resident expertise, to be appropriately sensitive to current debates about indigenous identity and reclamation of their culture and heritage?

Souvenirs are often highly prized items acquired during a vacation (Littrell, 1990). People purchase material goods not only for what they do, but also for what they mean (Levy, 1959). Souvenirs in particular carry strong semiotic messages in making intangible experiences tangible. Their existence in an office or home post-trip help tourists remember brief out-of-the-ordinary experiences that took place in extraordinary time when they are back in an everyday space and time (Gordon, 1986; Graburn, 1984). Graburn (2000) argues that an individual who brings a souvenir home can re-live the experience in routine time and space and it can thus become part of the extraordinary in some small way in an ordinary space.

At the same time souvenirs also promote damaging stereotypes, perpetuating myths. For example, large brimmed hats edged with corks, and large knives, are not usual attire for Australians but remain a prevalent image with negative connotations ranging from endemic violence to slow thinking. Mostly, negative images are justified by their producers as 'humor' but can be criticized as maligning, denigrating or belittling individuals or social groups (Apte, 1987; Barker, 1994). In contrast, negative humor can be used as a coping mechanism for individuals or groups (Coleman, 2000). Nevertheless, Ford and Ferguson (2004) suggest negative humor creates a norm tolerating prejudice and discrimination as it expands the bounds of appropriate conduct. Additionally, disparagement humor functions as a form of social control in which dominant social groups maintain their privileged positions (Sev'er \& Ungar, 1997).

Souvenirs perpetuating negative stereotypes create an environment of ridicule or hostility toward targeted groups at individual and macro-sociological levels (Irimoto, 2000, p. 217). Souvenirs thus have the potential to reinforce and maintain relative power imbalances between groups within a community. Assumptions about 'no intended harm' require a

This is an early version of a paper which eventually appears as Brennan, L., \& Savage, T. (2012). Cultural consumption and souvenirs: an ethical framework. Arts Marketing: an international journal, 2(2), 144-160. 
decision-making framework whereby commercial souvenir-makers can identify and manage their relationships with indigenous populations whose iconography forms such a strong part of the value chain. The presentation of images and discourses through souvenirs carries a strong message with far-reaching implications. It can be argued that souvenirs depicting minority indigenous groups in positive ways work towards creating an environment with more respectful attitudes toward indigenous people in the larger society. However, positive presentations of imagery are only one part of the story. We argue that the empowerment of others in indigenous decision-making with regard to the uses of their cultural heritage is also paramount in socially responsible conduct.

Empowerment names debates about Western colonialism inappropriately idealizing indigenous cultures (Olsen, 2008). In the tourism context, souvenirs are 'colonial treasures' in which tourists parallel early traders, colonists and missionaries (Stanley in Timothy, 2005, p. 103): souvenirs are items of esteem; they have intrinsic value for tourists as concrete evidence of visiting another place; they show something unique about that society and culture. Further, as mementos of individual leisure vacation time, souvenirs tell part of the story of a person's life (Kleine, Kleine \& Allen, 1995); in some cases they might even hold special value for an individual via self-extension (Belk, 1988). Souvenirs thus potentially build an individual's sense of self-worth and status. Conversely, souvenirs continue the spirit of colonization by controlling the images of a marginalized group, perpetuating white privilege and discrimination as acceptable.

How much consideration of social or cultural stereotypes and their impact is factored into designing and producing souvenirs is unknown. Nor is it known how much recompense is transmitted through the value chain to the originators of the imagery being used in artifacts. In general, souvenirs depict traditional or stereotypical aspects of a particular cultural group. In parts of the world that have been modernized and developed through colonization by powers such as the United States, Canada, South Africa, Australia, New Zealand, and Japan, indigenous people or practices are often represented in souvenirs of these nations. In Canada and the United States, popular souvenir items include Native American artifacts such as the cigar store Indian, feathered headdresses, Indian moccasins, totem poles, bows and arrows, jewelry of Indian design and miniature teepees - even in places the items were never used by the indigenous people of the area. Likewise in Australia, souvenir items tend to depict indigenous Australians in stereotypical ways as playing a didgeridoo, making bark paintings, or hunting with a spear (Edwards, 1996; Ryan \& Huyton, 1998), or as stockmen. In Japan, indigenous Ainu are often depicted wearing traditional headdresses and kimono with Ainu designs in woodcarvings accentuating deep-set eyes, strong chin lines and heavy eyebrows and beards (Savage, 2005).

In order to create a more equitable and peaceful society in the present, and sustain it into the future, an inclusive consultation process respecting the dignity and cultural uniqueness of indigenous people is overdue in the souvenir industry. This consultation process can be contained within a corporate responsible, ethical decision-making framework. Apart from stereotyped images used to represent indigenous people, indigenous societies have used their art works and handicrafts to communicate their cultural identity to the outside world (Timothy, 2005, p. 102). By selecting esteemed attributes and images, indigenous groups can portray themselves in a dignified and positive way. Souvenirs may potentially serve a political purpose in deliberately portraying an image that influences consumers' perceptions (Cohen, 1995; Shenhav-Keller, 1993).

In some countries laws underpin funding for indigenous people using their creative energies to produce commodified aspects of their culture including souvenirs (cf. Cheung, 2005; Savage, 2005). While this is available for indigenous entrepreneurship ventures, most souvenirs are mass-produced commercially by businesses, which are rarely owned by

This is an early version of a paper which eventually appears as Brennan, L., \& Savage, T. (2012). Cultural consumption and souvenirs: an ethical framework. Arts Marketing: an international journal, 2(2), 144-160. 
indigenous peoples and do not convey royalties to the indigenous creators. In addition to an outlet for indigenous creative energies, as items of exchange, souvenirs and other commodities carry meaning within the semiotic system (Dant, 1999; Miller, 1987; Morley, 1992). Baudrillard (1981, p. 147) regards consumption as "the stage where the commodity is produced as a sign and signs (symbols particular to a certain culture) are produced as commodities". As commodities are conceived as a material symbol of a social and economic system, they become part of the social discourse reflecting hierarchical modes of social organization and inequalities of power (de Certeau, 1984). The commodification of images from indigenous populations is fraught with issues of power and exploitation. Thus, what on the surface reads as the simple provision of esteem-enhancing artifacts to remember wonderful experiences can also be read as profiteering if originators of the imagery do not accumulate benefit along the value chain.

The situation for the Ainu in Japan provides a good example to illustrate these points with the passage of a law in 1997 for the Promotion of Ainu Culture and Dissemination and Advocacy for the Traditions of the Ainu and the Ainu Culture, usually known in English as the Ainu Cultural Promotion Act (CPA). This law provides funding for preservation and spread of Ainu cultural items and activities such as art, crafts, music, dance, dramatic performances and language, resulting in an increase in the amount of artworks and handicrafts for sale as souvenirs. The souvenir industry provides some Ainu with a means to make a living as well as a way to portray their identity, aimed at enhancing their prestige in the dominant community. However, Ainu are not the only producers of Ainu souvenirs and are therefore not in complete control of the way they are represented nor are they consulted about it. Observers note this is a contentious issue for politically aware Ainu who regard it as another form of exploitation steeped in a colonial mentality (cf. Cheung, 2005; Siddle, 2002). For this segment of the Ainu population, their struggle for reparation for the loss of their land and resources, culture and language continues today.

A similar situation exists for the indigenous people of Australia where the indigenous visual arts and crafts industry turns over US\$130 million, indigenous people receiving US\$30 million in 2002 (WIPO, 2004, p. 7). Brennan (in Assael, Pope, Brennan \& Voges, 2007, p. 480) observes Australian Aboriginal art has seen a proliferation of 'fake' works; and sometimes elderly people work for very little money, or cigarettes and alcohol. She notes unsuspecting tourists are buying such works from roadside communities mistakenly believing this is a more authentic distribution channel than purchasing artwork retail. Simons (2000) explains such artworks might be best distributed through channels returning profit on the intellectual property to the community or artist/author. A recent prosecution by the Australian Competition and Consumer Commission (2009) indicates a desire, at least by government, for indigenous works to be 'authentic' in that they should be produced by Australian indigenous persons. Internationally, arguments regarding the ownership of intellectual property are well documented, and there are legal frameworks in place to safeguard property rights. However, the ownership of indigenous imagery and the respective cultural iconography is not as well defined, nor are there evident legal and ethical frameworks for decision-making with regard to uphold individual or community intellectual property rights.

Souvenir items that reify indigenous minority groups are of interest in light of the variety of issues discussed above. Of particular importance is that souvenirs are designed to make a profit, and potentially for commercial organizations to exploit indigenous people, their culture and heritage. Ethics protocols to manage such practices suggest themselves as one part in making a positive contribution to the process of reconciliation between political majorities and indigenous people throughout the world.

\section{Corporate responsibility and the souvenir industry}

This is an early version of a paper which eventually appears as Brennan, L., \& Savage, T. (2012). Cultural consumption and souvenirs: an ethical framework. Arts Marketing: an international journal, 2(2), 144-160. 
Globally a trend has elaborated corporate social responsible strategies within tourism and other cultural consumption organizations (Bohdanowicz, 2007; Deery, Jago \& Stewart, 2007; UNWTO, 2005). While much of the discussion has focused on environmental issues such as eco-tourism (Engle, 2007; Schwartz \& Carroll, 2003), other issues are also important (Henderson, 2007). One issue not yet adequately addressed is the use of indigenous cultural images and objects, such as those already mentioned, by the souvenir industry. There is also a lack of an agreed framework for exactly what constitutes corporate social responsibility (Horrigan, 2007). This has caused a proliferation of actions that may or may not be 'responsible' depending on which stakeholder considerations are driving action (Banerjee, 2008).

One framework that does offer support for business decision-making is that of ethics and ethical behavior. Ethics defined as a code of moral principles on which to act or make decisions (Tsalikis \& Fritzsche, 1989), if followed appropriately to framework decisions, can avert or minimize need for other frameworks (Boyce, 2008). Stevens (2008), for example, argues developing organizational codes of conduct can encompass environmentally positive behaviors. Further, teaching ethical behavior at university can limit the overall damage done by the individual in the pursuit of organizational goals (Boyce, 2008). Many scholars support the notion that ethical decision-making is potentially feasible in business and advocate for the evolution of models that encompass social ethics in addition to business ethics (Fisscher \& Nijhof, 2005; Reidenbach \& Robin, 1990).

The other side of the argument reasons that adopting a legal framework implies organizations are unable to make ethical decisions regarding multiple stakeholders. Given the tensions involved, this might easily be the case. In a legal framework, businesses would be legally constrained to abide by codified principles of social equality, stipulated in laws and conventions, in the nation where souvenirs are sold. Of particular interest for indigenous people are the International Convention of the Elimination of All Forms of Racial Discrimination (CERD), the Convention Concerning Indigenous and Tribal Populations (CCITP), the International Covenant on Economic, Social and Cultural Rights (ICESCR), and the International Covenant on Civil and Political Rights (CCPR) (Stevens, 2001). If this were the case, business organizations would have a code of conduct externally applied to their behaviors.

It can be argued that global legal systems are a long way from such capacity to legislate and subsequently enforce compliance with an, as yet, undeveloped framework. Moreover, it is naïve to assume that in the absence of legal frameworks, ethical and/or moral frameworks could suffice. As Banerjee (2008, p. 8) observes, the literature on corporate social responsibility reveals that corporations are essentially guided by self-interests. However, since societies allow corporations to exist within them, corporations are morally obliged to operate ethically and with a social conscience. Banerjee contends the consequence of assuming corporations serve their own self interests is that they will therefore not implement social initiatives unless it is profitable to do so or are coerced by legislation. He asserts that since corporations lobby the government and have done so for over 200 years, the interests of nonshareholder groups will never be addressed in any meaningful way.

In contrast to these important negative insights into balancing stakeholder benefits, Margolis and Walsh (2003) argue that corporations do address social issues, pointing to the example of voluntary phasing out of chlorofluorocarbons because of the damage they cause to the ozone layer. When there are clear benefits to the corporation, environmental and social initiatives are more likely to be implemented. On the other hand, in clashes of interests and objectives, social justice issues may be ignored for corporate bottom lines. Market economy nations now face increasing global pressure towards reconciliation with indigenous groups. This may give businesses that take steps to recognize rights of indigenous people a strategic 
advantage. The following ethical guidelines propose a way for corporations to meet business needs while responsibly addressing issues of social justice for indigenous people.

\section{Developing guidelines for producers of souvenirs and cultural artifacts}

Given that commodities convey powerful messages to the general public, developing a set of principles to guide commercial entities that design and produce souvenirs relating to indigenous people has several potential benefits. Such guidelines need to consider the notion of the good 'corporate citizen' even though corporations are unlikely to engage in actions that disadvantage themselves. Advocates of the implementation of corporate responsibility in global business argue a holistic framework is needed in which social, cultural and political issues, themes and priorities are identified (Boggs, 1986). When combined with corporations addressing identified social risks or ills, Banerjee's (2008) notion of social accountability comes into play: how a corporation generates profits rather than the amounts of profits made.

Grice and Humphries's (1997) framing of corporations as the new colonialists, brings issues of exploitation and abusive practices into the open where they can be proactively addressed. This set of proposed guidelines relies heavily on ethical principles developed for researchers in anthropology based on the American Anthropological Association Code of Ethics (AAA, 2009). As a model, people are the central focus of anthropological research. It is argued that to redress social inequality and cultural marginalization, businesses and economic development must be centered on people not simply profit. The American Anthropological Association has taken on the mission of educating its members about ethical obligations and challenges concerned with the "generation, dissemination and utilization of anthropological knowledge" (p. 1).

This AAA Code applies ethical principles to the complex involvements and obligations of anthropologists and teachers who undertake projects with people less educated and/or less powerful politically, socially or economically. Linking this to corporate social accountability and how business practices affect people, should influence public opinion of them, which may in turn benefit their profitability. As every situation is different, the AAA Code is designed as a framework to be used as a decision-making tool rather than an ironclad formula (p. 1). Here, in addition to the AAA Code guidelines set up by the Centre for Clinical Research Excellence (CCRE) and the National Health and Medical Research Council (NHMRC) to guide medical researchers undertaking projects or study on indigenous people in Australia (Fredericks, 2008), were also used as resources.

These principles require researchers to engage the indigenous community from the onset. As Fredericks (2008) observes, Aboriginal and Torres Strait Islander peoples, and other indigenous people, are used to being the objects of research and are therefore aware of what research entails. It is thus appropriate and necessary to include indigenous people in the planning and implementation of a project through an inclusive consultation process before conducting research about them. Arguably, commercial organizations need to be alert to the demands of good citizenship when designing and producing souvenirs that relate to the reification of indigenous culture or people for sale to the general public.

The set of guidelines presented below have been modified to assist organizations that design souvenirs for indigenous or cultural tourism to better focus on the concerns of indigenous or minority people. The purpose of this code is to provide souvenir organizations with a set of principles for making negotiated ethical choices in their selection of designs that relate to indigenous people and their culture (material and spiritual). It is not intended this set of principles covers specific situations, but rather provides guidelines to assist organizations or individuals in making ethical decisions about their designs by developing an inclusive approach toward the minority group they undertake to depict in a cultural item. 


\section{Proposed guidelines: Responsibility to people and cultures depicted in cultural or souvenir items}

The primary ethical obligation is to the people and materials that are intended for representation in the souvenir item. These obligations can override the goal of making a profit and may lead to a decision to discontinue a design when the primary obligation conflicts with other responsibilities. It is paramount to include the people whose designs are being depicted in cultural artifacts or who are themselves reified in an item (or items) that are destined to be sold to the general public in discussions and negotiations. This is particularly relevant with indigenous people since indigenous art was not seen as being 'owned' by them but rather as a primitive manifestation of a disappearing culture. Further, as community owns the intellectual property and not the individual, this consultation should include community elders. Ethical obligations are of the utmost importance, and guidelines for engagement in consultation are outlined and rationalized below:

Actively consult with and engage the indigenous community in the conceptualization and creation of the souvenir item. Confirm support for the design of the souvenir item(s).

In order to protect the intellectual property rights of indigenous groups, consultation with indigenous communities concerned needs to proceed in such a way that both parties collect the information they need and feel comfortable in the consultation process. As indigenous people are as yet underrepresented in institutions of higher learning and the power differential between a business and an indigenous community is uneven, with the business entity in a more powerful position, organizations that are established in indigenous communities and have built up trust over a period of time could facilitate in the consultation process. Moreover, the culture clash of the two groups is also an important consideration in the consultation process. Therefore, considerations of the strategy used in this process are important, leading to the next guideline:

Agree on strategies for consultation and information collection. Organizations trusted by the indigenous communities could be helpful in this endeavor.

Cultural backgrounds between a mainstream business organization and an indigenous community are apt to be different. Consequently, it is important to repeatedly double-check the two parties have the same understanding of main points and agreements decided in meetings at various times through discussion and negotiation. The possibility for misinterpretation or miscommunication is higher when engaged in discussions or attempting to negotiate with people from a different cultural or linguistic background. Therefore, a feedback and verification process is suggested as a means of facilitating the success of the negotiations or discussions. The following point is advice concerning the process for verifying information:

Agree on feedback processes that will be put in place for verification of the information collected.

Indigenous intellectual property (designs) is still a significant legal cultural and social issue. Designs of indigenous people are considered part of tradition in their culture and are passed down from generation to generation, rather than being original designs created by an individual. Therefore, under intellectual property laws a large part of indigenous cultural material is regarded as being in the public domain (O'Brien, 1997). However, it is argued that commercial organizations using traditional indigenous designs in objects sold for profit are 
morally bound to show consideration for the indigenous community by offering a fair payment or engaging in a licensing agreement with them.

Acknowledge the individual or individuals or indigenous community for the use of their designs or images. Organizations could maintain Corporate Responsibility by offering payment to the community for the use of their designs and images as they are the creators of the designs used in the souvenirs.

It is important to let the entire community know the decisions that are made after discussions and negotiations take place. The way that information will be relayed to the indigenous community needs to be decided on from the outset through a negotiation process with elders or others that the community has appointed to represent them. It is important to realize that the indigenous community might also use a different language, which must also be factored into the negotiations or discussions with adequate translators involved, if necessary.

Agree on how the information will be circulated to the community. Translate if necessary.

Any depiction of the physical features of indigenous people is fraught with issues of stereotyping which can be damaging to the creation and maintenance of a positive social environment for the indigenous community within the wider society. Ensuring the privacy of an indigenous person or a community is also important in order to protect them from unwanted attention or exploitation.

Ensure you do not harm the dignity or privacy of the people represented in the souvenir item or who might reasonably be affected by the souvenir item.

While the protection of dignity and privacy are important, it is also important to acknowledge that each indigenous group is unique and culturally distinct. This is particularly important given that the communicative style or language may be different from other groups and this should be factored into the discussion or negotiation process.

Recognize the cultural distinctiveness of the indigenous group represented by the souvenir item.

As souvenir items are made for sale to the general public, items could be designed to improve knowledge about the history of the indigenous community and educate the wider community about them. The issue of reconciliation between peoples is at the core of this item. The design of the product can represent the indigenous group positively or negatively and it is possible to choose the positive imagery and still achieve profits.

Souvenir items should be designed with the idea of helping the majority and indigenous groups understand each other better.

More specifically, in order to avoid stereotyping and negative imagery, consultation with the indigenous elders and artists about the underpinning iconography and semiotics will be important. The representation of a stylized image of an indigenous person or indigenous people is perhaps more problematic in that the way they are physically depicted contributes to the semiotic context. Any representation of the physical features of an indigenous group is arguably contributing to a stereotype that can thereby prevent the possibility of the indigenous 
group achieving wider social equality. In addition, it is advisable to avoid the usage of depictions of an indigenous person in a position of deference in the souvenir item, even if it is unintentional. Souvenir items could also be produced that help educate the public about who the indigenous group are now, rather than perpetuate the myths of a romantic, stereotyped and/or made-up image.

Avoid perpetuating stereotypes of inferiority, expressing certain attitudes and sense of values cast in the mold of the majority in regards to the indigenous group represented in the souvenir item.

Concepts of informed consent are problematic in this context. However, in the production of souvenirs it is important to take all possible steps to identify the author as well as the depicted and to ensure that their permission for widespread reproduction is granted. This act is the fundamental difference between the potential for exploitation for corporate profits and the provision of corporate support for indigenous peoples. This is the beginning of the value chain.

Organizations that design or produce souvenir items must obtain informed consent of persons being represented or somehow identified by a souvenir design.

It must be remembered that just because an indigenous community engages in discussions or negotiations with an organization and they agree to a business relationship, the organization does not own them and does not speak for them. It is paramount to maintain respect and openness at all times. Respect might also mean that an artifact - no matter how profitable does not get produced.

Designers or producers of souvenir items must adhere to the obligations of openness and informed consent, while carefully and respectfully negotiating the limits of their relationship with the indigenous group.

Souvenir items that will be sold for profit need to benefit the indigenous community that is represented, not simply result in a profit for a business organization. Negotiations with the indigenous community could, for instance, centre around how the business organization will repay the community involved, remembering that a collective means of payment might be the fairest and most sustainable method of payment in which the business organization sets up a school or other institution that will benefit the entire community rather than make one-off payments to individuals from the indigenous community.

While organizations that design or produce souvenir items may gain from the sale of the souvenir items, they must not exploit individuals, groups or cultural materials. They should recognize their debt to the societies in which they obtained the designs and their obligation to reciprocate with the people represented in the souvenir item in appropriate ways.

Deception or deliberate misrepresentation of an indigenous group may invoke a penalty or fine for damages of either a psychological or financial nature. However, at present the legal framework for this is limited so moral decision-making should direct guidelines.

Organizations that design or produce souvenir items should not deceive or knowingly misrepresent an indigenous group. 
Finally, organizations that are engaged in the design, manufacture and sale of souvenir items that represent indigenous groups may choose to move beyond disseminating souvenirs to a position of advocacy. This is an organizational decision, but not an ethical responsibility. In light of the growth of community expectations regarding corporate responsibility, it might even be a sound business decision.

\section{Conclusion}

This paper has proposed a set of guidelines to enable ethical decision-making for business organizations that design and produce souvenirs depicting culture and heritage of indigenous populations. The guidelines are intended to help prevent stereotyping and the expropriation of indigenous culture by other more commercially-minded individuals or organizations. Although stereotyping and exploitation may well be unintentional, a framework for operation has been set up to make sure that segments of the indigenous population who do not fully participate in an industrial society are consulted about how their designs, image and identity are portrayed in souvenir items. The guidelines recommend a consultation process between the indigenous community and the organization that designs and produces the souvenirs. Most importantly, the establishment of effective communication channels to enable consultation with the indigenous community before, during and after creating an indigenous souvenir underpins a number of guidelines. Through consultation, stereotyping that might reflect popular misconceptions and misrepresentations of the group will be less likely to appear in a souvenir. The process of consultation would be a positive step in empowering indigenous groups by providing them with a voice on how their designs, culture and images will be represented for mainstream consumption. 


\section{References}

AAA. (2009), "Code of Ethics of the American Anthropological Association American Anthropological Association", available at:

http://www.aaanet.org/cs_upload/issues/policy-advocacy/27668_1.pdf (Accessed February 7, 2009)

Apte, M. (1987), "Ethnic humor versus "sense of humor": An American sociocultural dilemma", American Behavioral Scientist, Vol. 30 No. 1, pp. 27-41.

Australian Competition and Consumer Commission. (2009). ACCC institutes against seller of Aboriginal art for misleading representations. ACCC. http://www.accc.gov.au/content/index.phtml/itemId/877295 (Accessed June 26, 2009)

Banerjee, S. (2008), "Corporate social responsibility: The good, the bad and the ugly", Critical Sociology Vol. 34 No. 1, pp. 51-79.

Barker, K. (1994), "To be PC or not to be? A social psychological inquiry into political correctness", Journal of Social Behavior and Personality, Vol 9 No. 2, pp. 271-281.

Baudrillard, J. (1981), For a critique of the political economy of the sign, Telos Press, St. Louis, MO.

Belk, R. (1988), "Possessions and the extended self", Journal of Consumer Research Vol. 15 No. 2, pp. 139-168.

Berne Convention for the Protection of Literary and Artistic Works (1971, amended 1979), WIPO Database of Intellectual Property Legislative Texts http://www.wipo.int/treaties/en/ip/berne/trtdocs_wo001.html (Accessed July 9, 2010)

Boggs, C. (1986), Social movements and political power, Temple University Press, Philadelphia, PA.

Bohdanowicz, P. (2007), "A case study of Hilton environmental reporting as a tool of corporate social responsibility", Tourism Review International Vol. 11 No. 2, pp. 115131.

Boyce, G. (2008), "The social relevance of ethics education in a global(ising) era: From individual dilemmas to systemic crises", Critical Perspectives on Accounting, Vol. 19 No. 2, pp. 255-290.

Brennan, L. (2007), "Careful what you consume: Australian indigenous art", In H. Assael, N. Pope, L. Brennan, \& K. Voges (Eds.), Consumer behaviour (pp. 480-482). Wiley, Milton, QLD.

Coate, B. (2009), An economic analysis of the auction market for Australian art: Evidence of indigenous difference and creative achievement. (Unpublished doctoral dissertation). RMIT University, Melbourne, VIC.

Cheung, S. (2005), "Rethinking Ainu heritage: A case study of an Ainu settlement in Hokkaido, Japan”, Intercultural Journal of Heritage Studies Vol. 11 No. 3, pp. 197210.

Cohen, E. (1995), Contemporary tourism-trends and challenges: Sustainable authenticity or contrived post-modernity? In R. Butler \& D. Pearce (Eds.), Change in tourism: People, places, processes (pp. 12-29). Routledge, London.

Coleman, R. (2000), African American Viewers and the Black Situation Comedy: Situating Racial Humor. Garland, New York, NY.

Dant, T. (1999), Material culture in the social world, Open University Press, Buckingham, UK.

de Certeau, M. (1984), The Practice of everyday life, University of California Press, Berkeley, CA. 
Deery, M., Jago, L., \& Stewart, M. (2007), "Corporate social responsibility within the hospitality industry", Tourism Review International, Vol. 11 No. 2, pp. 107-114.

Edwards, E. (1996), "Postcards: Greetings from another world", In T. Selwyn (Ed.), The tourist image: Myths and myth making in tourism (pp. 197-221). Wiley, London.

Engle, R. (2007), “Corporate social responsibility in host countries: A perspective from American managers", Corporate Social Responsibility and Environmental Management, Vol. 14 No. 1, pp. 16-27.

Fiskesjö, M. (2009), "The Politics of cultural heritage”, In C. Lee \& Y. Hsing (Eds.), Reclaiming Chinese society: The new social activism (pp. 225-245). Routledge, London.

Fisscher, O. \& Nijhof, A. (2005), "Implications of business ethics for quality management", The TQM Magazine, Vol. 17 No. 2, pp. 150-160.

Ford, T. \& Ferguson, M. (2004), "Social consequences of disparagement humor: A prejudiced norm theory", Personality and Social Psychology Review, Vol. 8 No. 1, pp. 79-94.

Fredericks, B. (2008), "Making an impact researching with Australian Aboriginal and Torres Strait Islander peoples", Studies in Learning, Evaluation, Innovation and Development, Vol. 5 No. 1, pp. 21-35.

Gordon, B. (1986), "The souvenir: Messenger of the extraordinary", Journal of Popular Culture, Vol. 20 No. 3, pp. 135-146.

Graburn, N. (1984), "The evolution of tourist arts" Annals of Tourism Research, Vol. 11 No. 3, pp. 393-419.

Graburn, N. (2000), Foreword. In M. Hitchcock \& K. Teague (Eds.), Souvenirs: The material culture of tourism. (pp. xii-xvii). Ashgate, Aldershot, UK.

Grice, S. \& Humphries, M. (1997), "Critical management studies in postmodernity: Oxymorons in outer space?", Journal of Organizational Change Management, Vol. 10 No. 5, pp. 412-425.

Henderson, J. (2007), "Corporate social responsibility and tourism: Hotel companies in Phuket, Thailand, after the Indian Ocean tsunami", International Journal of Hospitality Management, Vol. 26 No. 1, pp. 228-239.

Hendry, J. (2005), Reclaiming culture: Indigenous people and self representation, Palgrave McMillan, New York, NY.

Horrigan, B. (2007), "21 st Century corporate social responsibility trends-An emerging comparative body of law and regulation on corporate social responsibility, governance, and sustainability", Macquarie Journal of Business Law, Vol. 4, pp. 85122.

ICESCR. (International Covenant on Economic, Social and Cultural Rights). (1966), Office of the United Nations High Commission for Human Rights, http://www2.ohchr.org/english/law/cescr.htm (Accessed November 2009)

Irimoto, T. (2000), Political movement, legal reformation and transformation of Ainu Identity. In M. Biesele, R., Hitchock \& P. Schweitzer (Eds.), Hunters and gatherers in the modern world: Conflict, resistance and self determination (pp. 206-221). Berghahn, Oxford UK.

Kleine, S., Kleine, R., \& Allen, C. (1995), "How is a possession "Me" or "Not Me"? Characterizing types and an antecedent of material possession attachment", Journal of Consumer Research, Vol. 22 No. 3, pp. 327-343.

Levy, S. (1959), "Symbols for sale”, Harvard Business Review, Vol. 3 No. 4, pp. 117-124. Littrell, M. (1990), "Symbolic significance of textile crafts for tourists", Annals of Tourism Research, Vol. 17 No. 2, pp. 228-245.

Margolis, J. \& Walsh, J. (2003), "Misery loves companies: Rethinking social initiatives by business", Administrative Science Quarterly, Vol. 48 No. 2, pp. 268-305.

This is an early version of a paper which eventually appears as Brennan, L., \& Savage, T. (2012). Cultural consumption and souvenirs: an ethical framework. Arts Marketing: an international journal, 2(2), 144-160. 
Michaels, E. (1994), Bad Aboriginal art, University of Minnesota Press, Minneapolis, MN. Miller, D. (1987), Material culture and mass consumption, Basil Blackwell, Oxford, UK. Morley, D. (1992), Television audiences and cultural studies, Routledge, London.

O’Brien, C. (1997), "Protecting secret sacred designs-Indigenous culture and intellectual property law", Media and Arts Law Review 2, pp. 57-76.

Olsen, K. (2008), "The Maori of tourist brochures representing indigenousness", Journal of Tourism and Cultural Change, Vol. 6 No. 3, pp. 161-184.

Reidenbach, R., \& Robin, D. (1990), "Toward the development of a multidimensional scale for improving evaluations of business ethics", Journal of Business Ethics, Vol. 9 No. 8, pp. 639-653.

Ryan, C. \& Huyton, J. (1998), "Dispositions to buy postcards with Aboriginal designs at Ulu ru-Kata Tjuta National Park", Journal of Sustainable Tourism, Vol. 6 No. 3, pp. 254259.

Savage, T. (2005). The effects of commodification and museumification of Ainu on language revitalisation and maintenance, (Unpublished doctoral dissertation). La Trobe University, Melbourne, VIC.

Schwartz, M., \& Carroll, A. (2003), "Corporate social responsibility: A three domain approach", Business Ethics Quarterly, Vol. 13 No. 4, pp. 503-530.

Sev'er, A., \& Ungar, S. (1997), "No laughing matter: Boundaries of gender-based humour in the classroom", Journal of Higher Education, Vol. 68 No. 1, pp. 87-105.

Shenhav-Keller, S. (1993), "The Israeli souvenir: Its text and context", Annals of Tourism Research, Vol. 20 No. 1, pp. 182-196.

Siddle, R. (2002), “An epoch-making event? The 1997 Ainu Cultural Promotion Act and its impact", Japan Forum, Vol. 14, No. 3, pp. 405-423.

Simons, M. (2000), "Aboriginal heritage art and moral rights", Annals of Tourism Research, Vol. 27 No. 2, pp. $412-431$.

Stevens, B. (2008), "Corporate ethical codes: effective instruments for influencing behavior", Journal of Business Ethics, Vol. 78 No. 4, pp. 601-609.

Stevens, G. (2001), "The Ainu and human rights: Domestic and international legal protections", Japanese Studies, Vol. 21 No. 2, pp. 181-198.

Timothy, D. (2005), Shopping tourism, retailing, and leisure, Channel View Publications, Buffalo, NY.

Tsalikis, J. \& Fritzsche, D. (1989), "Business ethics: A literature review with a focus on marketing ethics", Journal of Business Ethics, Vol. 8 No. 9, pp. 695-743.

UNWTO (2005), Report of the World Tourism Organization to the United Nations SecretaryGeneral in preparations for the High Level Meeting on the Mid Term Comprehensive Global Review of the Program of Action for the Least Developed Countries for the Decade 2001-2010. http://www.un.org/specialrep/ohrlls/ldc/MTR/WorldTourisninput.pdf (Accessed Nov 10, 2011).

UNWTO (2008), Tourism highlights: 2008 edition. http://www.unwto.org, Retrieved May 15, 2010.

WIPO. (World Intellectual Property Organization). (2004). Intellectual Property and Traditional Cultural Expressions. WIPO Publication No. 913(E), http://www.wipo.int/freepublications/en/tk/913/wipo_913.pdf (Accessed June 20, 2010) 